\title{
Role of beta-arrestin 2 downstream of dopamine receptors in the basal ganglia
}

\section{Thomas Del'Guidice, Morgane Lemasson and Jean-Martin Beaulieu*}

Department of Psychiatry and Neuroscience, Faculty of Medicine, Centre de Recherche Université Laval Robert-Giffard, Québec, QC, Canada

Edited by:

Emmanuel Valjent, Université

Montpellier 1 \& 2, France

\section{Reviewed by:}

Takehsi Kaneko, Kyoto University, Japan

Gordon Arbuthnott, Okinawa Institute of Science and Technology, Japan Laura M. Bohn, The Scripps Research Institute, US Minor Outlying Islands Stefano Marullo, Institut Cochin, France

*Correspondence:

Jean-Martin Beaulieu, Centre de Recherche Université Laval Robert

Giffard, 2601 Chemin de la

Canardière, Suite F-6500, Beauport,

Québec, QC, Canada G1J 2G3.

e-mail:martin.beaulieu@crulrg.

ulaval.ca
Multifunctional scaffolding protein beta-arrestins ( $\beta A r r)$ and the $G$ protein-receptor kinases are involved in the desensitization of several G protein-coupled receptors (GPCR). However, arrestins can also contribute to GPCR signaling independently from G proteins. In this review, we focus on the role of $\beta$ Arr in the regulation of dopamine receptor functions in the striatum. First, we present in vivo evidence supporting a role for these proteins in the regulation of dopamine receptor desensitization. Second, we provide an overview of the roles of $\beta$ Arr2 in the regulation of extracellular-signal-regulated kinases/MAP kinases and Akt/GSK3 signaling pathways downstream of the D1 and D2 dopamine receptors. Thereafter, we examine the possible involvement of $\beta$ Arr-mediated signaling in the action of dopaminergic drugs used for the treatment of mental disorders. Finally, we focus on different potential cellular proteins regulated by $\beta$ Arr-mediated signaling which could contribute to the regulation of behavioral responses to dopamine. Overall, the identification of a cell signaling function for $\beta$ Arr downstream of dopamine receptors underscores the intricate complexity of the intertwined mechanisms regulating and mediating cell signaling in the basal ganglia. Understanding these mechanisms may lead to a better comprehension of the several roles played by these structures in the regulation of mood and to the development of new psychoactive drugs having better therapeutic efficacy.

Keywords: dopamine, arrestin, glycogen synthase kinase,Akt/protein kinase B, MAP kinase, striatum, biased ligand pharmacology, G protein-coupled receptors

\section{INTRODUCTION}

Dopamine is a catecholamine neurotransmitter that has several functions in the brain including the regulation of locomotion, cognition, emotions, and endocrine secretion (for review see Carlsson, 2001). Consequently, abnormal dopamine signaling could be implicated in many neuropsychiatric disorders such as schizophrenia, bipolar disorder, depression, Parkinson's disease, and drug abuse. This broad functional implication of the dopaminergic system is, at least in part, explained by its prominent cerebral innervation.

Anatomically, dopamine neurons extend widely in the central nervous system and could be dissociated in five sub-systems: nigrostriatal, mesolimbic, mesocortical, tuberoinfundibular, and tuberohypophysial (Bannon et al., 1983; Bjorklund and Stenevi, 1984). Among these, one of the major dopamine containing regions is the nigrostriatal pathway, composed of dopamine neurons originating from substantia nigra and ventral tegmental area that project respectively to the caudate putamen and nucleus accumbens, among other areas (Gerfen and Surmeier, 2011).

Dopamine signaling is mediated by two different groups of G protein-coupled receptors (GPCR). The first category, the D1 family, comprises the D1- and D5-receptors (D1R and D5R). The second family, named D2-class receptors, is formed by the D3R, D4R along with the short and long splices variants of the D2R (for a review see Missale et al., 1998; Beaulieu and Gainetdinov, 2011). In the basal ganglia, D1R is mostly expressed by GABAergic medium spiny neurons (MSN) of the caudate putamen (striatum) while D2R are found in both MSN and dopamine neurons. Recent studies using bacterial artificial chromosome (BAC) transgenic mice expressing specific reporters (e.g., eGFP and/or dtTomato) under the control of the D1R or D2R gene promoters, revealed a high level of segregation of D1R- and D2R-containing MSN (Figure 1) of the striatum and nucleus accumbens (Shuen et al., 2008; Valjent et al., 2009). These data confirmed that MSN could be separated into two subgroups according to their projection areas and the type of dopaminergic receptors that they express. One of these subgroups includes MSN of the direct striatonigral pathway, which mostly express D1R, and project to the medial globus pallidus and substantia nigra pars reticulata. The second group is composed of MSN of the "indirect" striatopallidal track that project to the lateral globus pallidus and express preferentially D2R (Gerfen and Surmeier, 2011). In the striatum, activation of D1R appears to facilitate transmission along the direct pathway while activation of post-synaptic D2R would inhibit transmission along the indirect pathway (Parent et al., 2000; Kravitz et al., 2010). However, it is noteworthy that a small subpopulation of MSN synthesizes both D1R and D2R and may have different dopamine receptor signaling properties (Rashid et al., 2007; Valjent et al., 2009).

Functionally, dopamine receptors signal through $G$ proteindependent cellular processes. D1R is mostly coupled to Gas/olf proteins and stimulate the activity of adenylate cyclase and the production of the second messenger cAMP (Spano et al., 1978; 


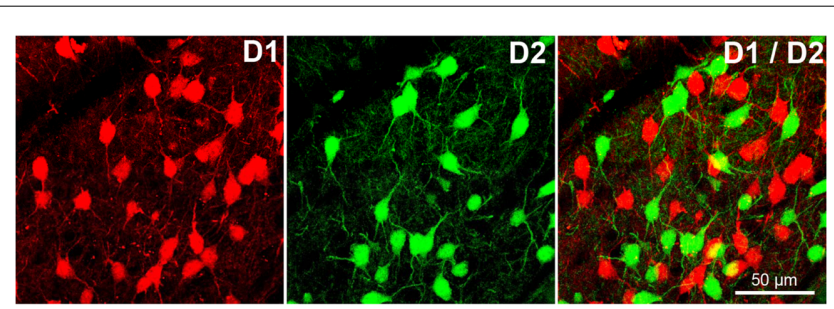

FIGURE 1 | D1 and D2 receptors are segregated in different cells in the striatum and in the nucleus accumbens. The first image (left) shows striatal cells of the direct striatonigral pathway expressing D1 receptors (specific reporter dtTomato under the control of D1R promotor). Second image (middle) show striatal cells of the indirect striatopallidal track expressing D2 receptors (specific reporter eGFP under the control of D2R promotor). The third picture (right) shows the lack of colocalization of D1 and D2 receptors in striatal cells (yellow parts of cells are cell overlap artifacts)

Kebabian and Calne, 1979). In contrast, D2R is associated to Gai/o proteins and inhibit the production of cAMP. The coupling of dopamine receptors to different $G$ proteins allows this neurotransmitter to act on multiple cell signaling molecules such as kinases and phosphatases (Beaulieu and Gainetdinov, 2011). As for other GPCR, activation of dopamine receptors is quickly followed by their rapid phosphorylation by GPCR kinases ( $G$ protein-receptor kinases, GRK; Premont and Gainetdinov, 2007). This results in the recruitment of multifunctional scaffolding proteins termed beta-arrestin 1 and beta-arrestin 2 ( $\beta$ Arr 1 and $\beta A$ rr2) in order to desensitize and internalize GPCR (Gainetdinov et al., 2004; Shenoy and Lefkowitz, 2005). The recruitment of at least $\beta$ Arr2 to D1R and D2R has also been reported to activate cellular signaling in a $G$ protein-independent manner by inducing the formation of functional protein complexes in which $\beta$ Arr acts as a scaffold for different kinases and phosphatases (Beaulieu et al., 2005; Urs et al., 2011).

In this review, we provide an overview of our current understanding of the different contributions of $\beta$ Arr to dopamine receptor functions putting an emphasis on studies conducted directly in the mouse striatum. First, we present an outline of in vivo studies of the involvement of $\beta$ Arr and GRK in dopamine receptor desensitization and internalization. We then summarize different lines of evidence supporting the implication of $\beta$ Arr-dependent signaling events downstream of both D1R and D2R. Thereafter, we examine the possible involvement of $\beta$ Arr and its molecular interactors in the action of drugs used for treatment of psychiatric disorders. Finally, we discuss briefly evidences pointing toward possible molecular mechanisms through which $\beta$ Arr-mediated signaling can contribute to the regulation of neuronal functions by dopamine.

\section{A ROLE FOR BETA-ARRESTIN IN THE REGULATION OF DOPAMINE RECEPTOR FUNCTIONS}

Following receptor stimulation, homologous GPCR desensitization constitutes a crucial mechanism to protect cells against overstimulation of the receptors. This phenomenon begins with the phosphorylation at specific sites of the activated GPCR by GRK. This first step is followed by the recruitment and the binding of the multifunctional adaptor proteins arrestins (Lohse et al., 1990a; Pitcher et al., 1998; Pierce and Lefkowitz, 2001; Gainetdinov et al., 2004; Premont, 2005). Association of $\beta$ Arr to GPCR prevents further $G$ protein activation therefore ensuing receptor desensitization (Lohse et al., 1990b). $\beta$ Arr also promote receptor internalization from the cellular membrane to the cytoplasm through the subsequent binding of arrestins to the clathrin adaptor protein adaptin (AP2; Laporte et al., 2002) and to clathrin itself (Krupnick et al., 1997). This process triggers clathrin-mediated endocytosis of the receptor and either its subsequent recycling to the cell surface or degradation (Figure 2; Ferguson et al., 1996; Ferguson, 2001; Claing et al., 2002; Claing and Laporte, 2005). Dopamine receptor activity is modulated by desensitization via $\beta$ Arr 1 and $\beta$ Arr 2 . Evidences that support the involvement of $\beta$ Arr 1 in the regulation of D1R and D2R, come from in vitro studies (Kim et al., 2001; Oakley et al., 2001). Furthermore, research conducted in heterologous cellular systems also indicates a role for $\beta$ Arr2 in desensitization of D1R, D2R, and D3R (Kim et al., 2001; Oakley et al., 2001; Gainetdinov et al., 2004; Lan et al., 2009). Thus, $\beta$ Arr proteins could serve as key regulators in dopamine receptor activity.

In vivo studies using different enhancers of dopamine neurotransmission (cocaine and amphetamine) and dopamine agonists (apomorphine), have resulted in a more complex picture of the role of arrestins in dopamine receptor functions (Gainetdinov et al., 2004; Beaulieu et al., 2009). The psychostimulants cocaine and amphetamine both affect the functions of the dopamine transporter (DAT) and induce an increase of extracellular dopamine levels, resulting in over-stimulation of dopamine receptors. In normal mice, enhancement of striatal dopaminergic activity following acute administration of these drugs leads to a hyperactive locomotion phenotype. Impairment of desensitization by deleting one of its mediators, GRK6, in GRK6-knock-out mice (GRK6-KO), exacerbates psychostimulant-induced hyperactivity as compared to wild-type (WT) animals (Gainetdinov et al., 2003). Furthermore, characterization of dopamine receptor functions in these mice has shown that a lack of GRK6 results in reduced D2R desensitization. This indicates that impaired desensitization of dopamine receptors in mice lacking GRK6 actively contributes to enhanced locomotor response to psychostimulants acting on dopaminergic neurotransmission.

Surprisingly, inactivation of other components of the desensitization machinery such as $\beta$ Arr 1 and $\beta$ Arr2 does not reproduce the behavioral effects observed in GRK6-KO mice after dopaminergic drugs exposure. Indeed, $\beta$ Arr1-KO and $\beta$ Arr2$\mathrm{KO}$ mice both display a reduced behavioral responsiveness to the non-selective dopamine agonist apomorphine (Gainetdinov et al., 2004; Beaulieu et al., 2005). In addition, reduced locomotor responsiveness to amphetamine has also been reported in $\beta$ Arr2KO mice (Beaulieu et al., 2005) while behavioral responsiveness to cocaine does not appear to be affected by an absence of either $\beta$ Arr1 or $\beta$ Arr2 (Bohn et al., 2003; Gainetdinov et al., 2004). $\beta$ Arr2 also appears to contribute to the dopamine-dependent effect of the opiate drug morphine. Administration of morphine in mice produces locomotor hyperactivity by increasing dopamine release from the presynaptic terminals (Kuschinsky and Hornykiewicz, 1974). Interestingly, this behavioral effect of enhanced dopamine neurotransmission resulting from morphine administration has 

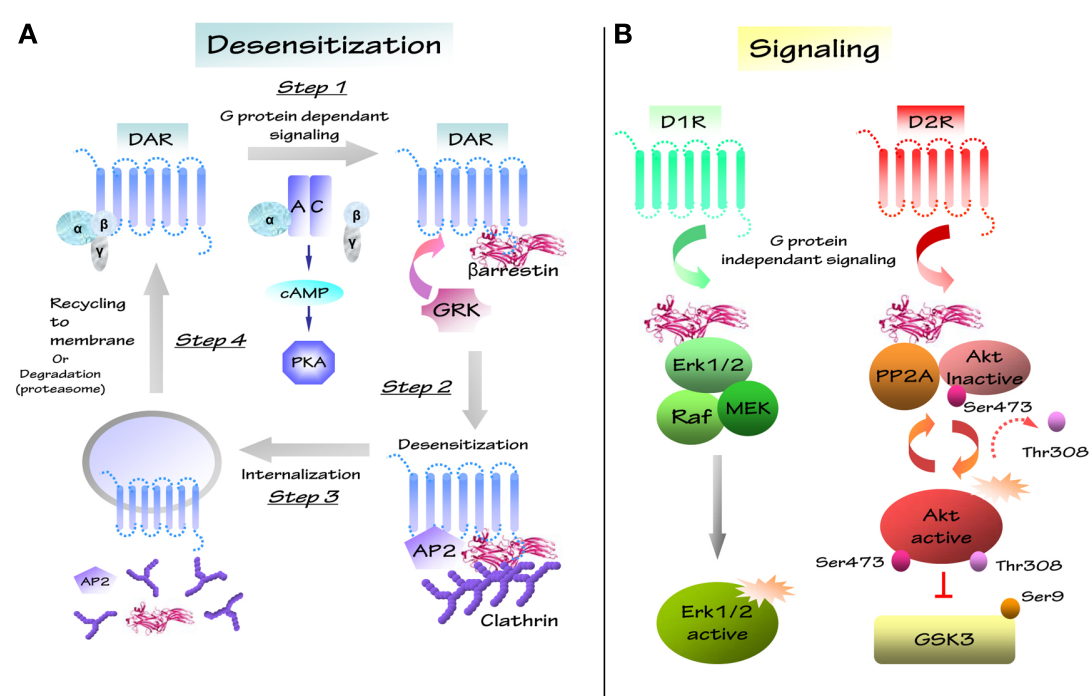

FIGURE 2 | Schematic representation of dopaminergic desensitization and signaling. (A) After stimulation, GPCR/DAR regulates different second messengers like adenylate cyclase (AC), cyclic adenosine monophosphate (cAMP), protein kinase $A$ (PKA) in a $G$ protein-dependent way (step1). Signaling induces the recruitment of $G$ protein-receptor kinases family (GRK) and of multifunctional scaffolding protein $\beta$ arrestin, which induce the formation of the receptor/protein complex (GPCR/AP2//3arrestin/clathrin; step2). GPCR-associated protein complex is internalized in clathrin coated-pits and complex is disassembled (step3). Internalized GPCR is recycled to membrane or degradated by proteasome (step4). (B) D1 and D2 receptors can regulate several molecular pathways through different G protein-independent signalling. D1 receptor (D1R) may regulates protein complex composed of $\beta$ arrestin 2/Erk/Raf/MEK and induces Erk activation. D2 receptor (D2R) modulates the Akt/Barrestin 2/PP2A protein complex and the Akt downstream substrate GSK3 that is inhibited by Akt. also been reported to be reduced in mice deficient for $\beta$ Arr2 (Bohn et al., 2003). Finally, the locomotor consequences of a genetic enhancement of dopamine tones also appear to be partially counteracted by a loss of $\beta$ Arr2. In mice, genetic deletion of the DAT abolishes dopamine reuptake (Jones et al., 1998). This induces an increase of extra synaptic dopamine levels and subsequent hyperactive phenotype (Giros et al., 1996; Gainetdinov et al., 1999). However, double mutant mice lacking both $\beta$ Arr2 and the DAT display a reduction in this novelty-induced locomotor hyperactivity phenotype (Beaulieu et al., 2005). Overall, results from these different studies indicate that a lack of $\beta$ Arr1 or $\beta$ Arr2 leads to a reduction in the locomotor response to dopamine receptor stimulation. The only major exception is locomotor response to acute cocaine, which is not overtly affected by a lack of either $\beta$ Arr1 or $\beta$ Arr2. The reasons these discrepancies remain obscure. One possibility is that acute cocaine administration may trigger locomotors responses by acting also on other neurotransmitter systems. In line with this, it is of interest that acute but not chronic locomotors response to cocaine has been shown to be severely reduced in mice expressing low levels of the glutamate/NMDA receptor subunit NR1 while locomotors responses to amphetamine were left essentially unaffected in these mice (Ramsey et al., 2008).

In conclusion, while $\beta A R$ and GRK appear to play a role in dopamine receptor desensitization and internalization in cultured cells systems, this role is only clearly supported at the behavioral level by data obtained in GRK6-KO mice. In contrast, lack of $\beta$ Arr has either a minimal effect or reduced the behavioral responsiveness to certain drugs acting on dopamine functions therefore suggesting that $\beta$ Arr may be implicated in different cellular processes regulating dopaminergic signaling and locomotor behaviors (Beaulieu et al., 2005, 2007a; Urs et al., 2011).

\section{REGULATION OF ERK/MAP KINASE SIGNALING BY $\beta$ Arr2 AND D1R}

Dopamine receptor-regulated behaviors are frequently associated to the activation of extracellular-signal-regulated kinases (ERK)/MAP kinase signaling (Beaulieu et al., 2006; Girault et al., 2007; Beaulieu and Gainetdinov, 2011). The serine threonine kinase ERK is positively regulated following its phosphorylation by the MAP kinase-kinase, MAPK/ERK kinase (MEK) that is itself activated by the MAP kinase-kinase-kinase RAF following the activation of different types of receptors including several receptor tyrosine kinases (RTK) and GPCR (Girault et al., 2007). Different lines of evidence have demonstrated the importance of ERK-mediated signaling in the maintenance of dopamine receptor functions. For instance, activation of D1R has been shown to activate ERK in the mouse striatum while conversely inhibition of ERK leads to reductions of hyper-locomotor responses in DAT-KO mice or following administration of amphetamine or cocaine (Berhow et al., 1996; Valjent et al., 2000, 2006a; Beaulieu et al., 2006; Girault et al., 2007). Furthermore, activation of ERK by dopamine receptors also appears to play an important role in longterm changes in synaptic plasticity in response to drug of abuse (Miller and Marshall, 2005) or in response to L-DOPA therapy for Parkinson's disease (Santini et al., 2007).

In transfected cells, $\beta$ Arr2 can support the formation of a mitogen activated protein kinase (MAP kinase) complex composed of $\beta$ Arr2 and the MAP kinase pathway kinases RAF, MEK, and ERK in response to GPCR activation (Ahn et al., 2004; Shenoy 
and Lefkowitz, 2005) resulting in an activation of ERK (Luttrell et al., 2001; Wei et al., 2004; Luttrell and Gesty-Palmer, 2010). Therefore, $\beta$ Arr2 may serve to promote ERK-mediated signaling underlying dopamine-regulated behaviors. Recent evidence suggests that $\beta A$ Arr2 may participate in locomotor response and activation of ERK in response to D1R stimulation. Urs et al. (2011) have reported that acute morphine administration increases the interaction between $\beta$ Arr2 and ERK in the striatum of WT but not of D1R-KO mice as measured by co-immunoprecipitation assays. In addition, morphine-dependent locomotion and activation of striatal ERK2 by morphine were curtailed in mice lacking either the D1R or BArr2. Finally, co-administration of the indirect ERK inhibitor SL327 along with morphine to WT mice also reduced the locomotor response to morphine. This suggests that the D1R may regulate ERK signaling and may contribute to the dopamine-mediated locomotor responses to morphine by acting via a $\beta$ Arr2-dependent mechanism. However, there is also strong evidence for a role of canonical G protein/cAMP-mediated mechanisms in the regulation of ERK activity by D1R (Girault et al., 2007). Therefore, results obtained in this study following administration of SL327 or in D1R-KO mice may also reflect an effect of these experimental conditions on other D1R receptor signaling mechanisms and further studies are needed to establish the contribution of $G$ protein and $\beta A$ rr2 in the regulation of ERK activity and behavior by D1R.

\section{THE REGULATION OF Akt AND GSK3 BY DOPAMINE AND BETA-ARRESTIN 2}

Over the years, several lines of evidence have pointed toward the contribution of $\beta$ Arr-mediated mechanisms in the regulation of Akt and GSK3, two serine/threonine kinases, by dopamine.

Akt, also termed protein kinase B, is known to be involved in various cellular processes such as transcription, glucose metabolism, proliferation, migration, and with insulin and neurotrophin action through the stimulation of RTK (Cross et al., 1995; Alessi et al., 1996; Scheid and Woodgett, 2001). Activation of RTK and some GPCR regulates the phosphoinositol-3 kinase (PI3K), which converts phophatidyl-inositol-2-phosphate (PIP2) to phosphatidyl-inositol-3-phosphate (PIP3; For review, Martelli et al., 2010). Then, the newly formed PIP3 interacts with the pleckstrin homology domain of Akt, inducing its recruitment to the plasma membrane. This cellular process results in the phosphorylation of Akt at threonine 308 and serine 473 residues by two phosphatidyl-dependent kinases, PDK1 and PDK2/rictor-mTOR, respectively (Scheid and Woodgett, 2001; Jacinto et al., 2006). Once activated, Akt phosphorylates in turn several substrates including GSK3 (Rossig et al., 2002).

Originally known for its role in the control of glycogenesis in response to insulin, GSK3 is implicated in numerous physiological processes such as embryonic development, cell differentiation, cell survival, Wnt signaling, apoptosis as well as serotonin, and dopamine receptor signaling (Woodgett, 2003; Beaulieu et al., 2004, 2008b; Li et al., 2004). Mammalian cells express two isoforms of GSK3, GSK $3 \alpha$, and GSK3 $\beta$, which are constitutively active and can phosphorylate several cellular substrates (Woodgett, 1990). GSK3 $\alpha$ and GSK3 $\beta$ are negatively regulated by several kinases involved in PI3K and MAP kinases signaling pathways (Frame and Cohen, 2001). Additionally, Akt phosphorylation inhibits the two isoforms of GSK3 in response to growth factors and hormones, including BDNF, IGF, and insulin (Yamada et al., 2002; Altar et al., 2008). Specifically, Akt phosphorylates specific residues serine 21 for GSK3 $\alpha$ and serine 9 for GSK3 $\beta$ that are located in the N-terminal domains of both GSK3 isoforms (Stambolic and Woodgett, 1994; Frame and Cohen, 2001). Therefore, Akt is an important regulator of various signaling cascades involving GSK3.

Experiments using DAT-KO mice, dopamine depletion or dopamine receptors agonist/antagonists have provided converging evidence for a negative regulation of Akt resulting in an activation of GSK3 isoforms by D2-class receptors in mammals and other vertebrates (Beaulieu et al., 2004; Bychkov et al., 2007; Chen et al., 2007; Souza et al., 2011). Consequently, pharmacological D2-class receptors antagonists induce Akt activation and subsequent GSK3 inhibition (Beaulieu et al., 2004; Emamian et al., 2004). Furthermore, experiments conducted using mice lacking different dopamine receptors showed that a loss of D2R but not D1R prevented the inactivation of striatal Akt by drugs acting on dopamine neurotransmission (Beaulieu et al., 2007b). In contrast, mice deficient for the $\mathrm{D} 3 \mathrm{R}$ exhibit a reduced responsiveness of Akt phosphorylation to dopaminergic drugs. Therefore, D2R would be crucial for the inhibition of Akt by dopamine, while the D3R appears to potentiate the D2R dopamine response (Beaulieu et al., 2007b).

It has been demonstrated that $\beta$ Arr2 is actively involved in dopamine-regulated Akt inhibition (Beaulieu et al., 2004, 2005). The role of $\beta A$ rr2 in mediating the regulation of Akt and GSK3 by $\mathrm{D} 2 \mathrm{R}$ is supported both by behavioral and direct in vivo biochemical observations in pharmacological and genetic models of enhanced dopamine neurotransmission. At the behavioral level, $\beta$ Arr2-KO mice present lower locomotor activity in response to the dopamine-dependent action of amphetamine and apomorphine (Gainetdinov et al., 2004; Beaulieu et al., 2005). In line with this, increased locomotor activity observed in mice lacking the DAT is also antagonized by the absence of $\beta$ Arr 2 in double knockout animals (Beaulieu et al., 2005). At the biochemical level, both amphetamine and apomorphine have been shown to inhibit the phosphorylation and activation of Akt in the striatum of WT mice while these two drugs failed to inhibit Akt in $\beta A$ Arr2-KO mice. Furthermore, genetically increased dopaminergic tones were also shown not to affect Akt activity in mice deficient for both DAT and $\beta A$ Arr2, suggesting an important role of this scaffolding protein in Akt regulation by dopamine. Further characterization of the molecular mechanisms underlying the regulation of Akt by D2R following receptor stimulation has shown that $\beta$ Arr 2 is involved in the formation of a protein complex composed of Akt, $\beta$ Arr2, and protein phosphatase 2A (PP2A; Beaulieu et al., 2005). Once in the complex, PP2A dephosphorylates and deactivates Akt, resulting in the activation of GSK3 (Beaulieu et al., 2004, 2005).

One interesting observation emerging from the regulation of this pathway is a difference of kinetics that points toward the existence of two modalities of cell signaling responses to slow synaptic neurotransmission. Indeed, inhibition of Akt is a slower and more persistent phenomenon than events mediated by the cAMP-PKA pathway (Beaulieu et al., 2004, 2005, 2007a). On the one hand, administration of amphetamine in mice induces 
a cAMP-dependent phosphorylation of ERK and DARPP-32 during the first $30 \mathrm{~min}$ after drug administration (Valjent et al., 2005). On the other hand, Akt inhibition following acute treatment with amphetamine becomes significant after $30 \mathrm{~min}$ and persists over the duration of the drug behavioral effects (Beaulieu et al., 2007a, 2005). These different kinetics suggest that dopamine-regulated behaviors and action of dopaminergic drugs depend, at least in part, from different and temporally successive waves of GPCR signaling mediated respectively by $\mathrm{G}$ proteins and the $\beta$ Arr 2 .

\section{ARRESTIN/Akt/GSK3, DOPAMINE SIGNALING AS A TARGET FOR MOOD STABILIZERS}

The most prescribed and studied mood stabilizer, lithium, is known for its therapeutic effects in the treatment of bipolar disorders (Cade, 1949; Schou et al., 1954; Phiel and Klein, 2001; Blanco et al., 2002). However more than 60 years after its introduction, the molecular mechanisms underlying the therapeutic actions of lithium are still unknown. Among other proposed mechanisms, lithium can directly and indirectly inhibit the activity of GSK3 (Stambolic et al., 1996; O'Brien and Klein, 2009). In mice, indirect inhibition of GSK3 occurs following the activation of its direct regulator Akt (Chalecka-Franaszek and Chuang, 1999; Beaulieu et al., 2004, 2008a). It has recently been demonstrated that this effect of lithium on the activity of Akt could be mediated by $\beta$ Arr2, at least in the mouse striatum (Beaulieu et al., 2008a). Biochemically, lithium disrupts the $\beta$ Arr2/Akt/PP2A signaling complex that is regulated by D2R (Figure 3 ). This leads to an overactivation of Akt and subsequent indirect GSK3 inhibition. In $\beta A$ rr2-KO mice, lithium fails to inhibit GSK3 and to activate Akt as it does in the striatum of WT mice (Beaulieu et al., 2008a). Furthermore, in these mutant mice, chronic treatment with lithium does not exert antimanic and antidepressant-like effects seen in control animals. This finding provides strong correlative evidence that lithium could exerts some of its biochemical and behavioral effects by interfering with the dopamine associated- $\beta$ Arr 2 signaling complex involved in the regulation of Akt and GSK3. This possible mechanism of action is further supported by recent observations indicating that expression of the Akt isoform Akt1 is also essential for the regulation of some behaviors by lithium in mice (Pan et al., 2011). Interestingly, other mood stabilizers such as valproic acid and lamotrigine might also modulate Akt/GSK3 signaling (Chen et al., 1999; Li et al., 2002; Beaulieu and Caron, 2008). Indeed, both mood stabilizers decrease the phosphorylation of GSK3 substrates (Gould and Manji, 2005). However, these different drugs have to be further studied to investigate a possible involvement of Akt/GSK3 signaling in their therapeutic effects.

\section{A ROLE FOR Akt AND GSK3-MEDIATED DOPAMINE SIGNALING IN THE ACTION OF ANTIPSYCHOTICS}

Antipsychotics are a heterogeneous family of drugs used for the treatment of several psychiatric disorders, mostly schizophrenia. Among these drugs, so called first generation or "typical" antipsychotics like haloperidol and chlorpromazine are believed to exert most of their therapeutic action in schizophrenia by blocking D2class receptors (Snyder, 1976). In addition, more recent second generation or "atypical" antipsychotics (AA) like clozapine have been shown to retain D2-class receptor antagonist functions while

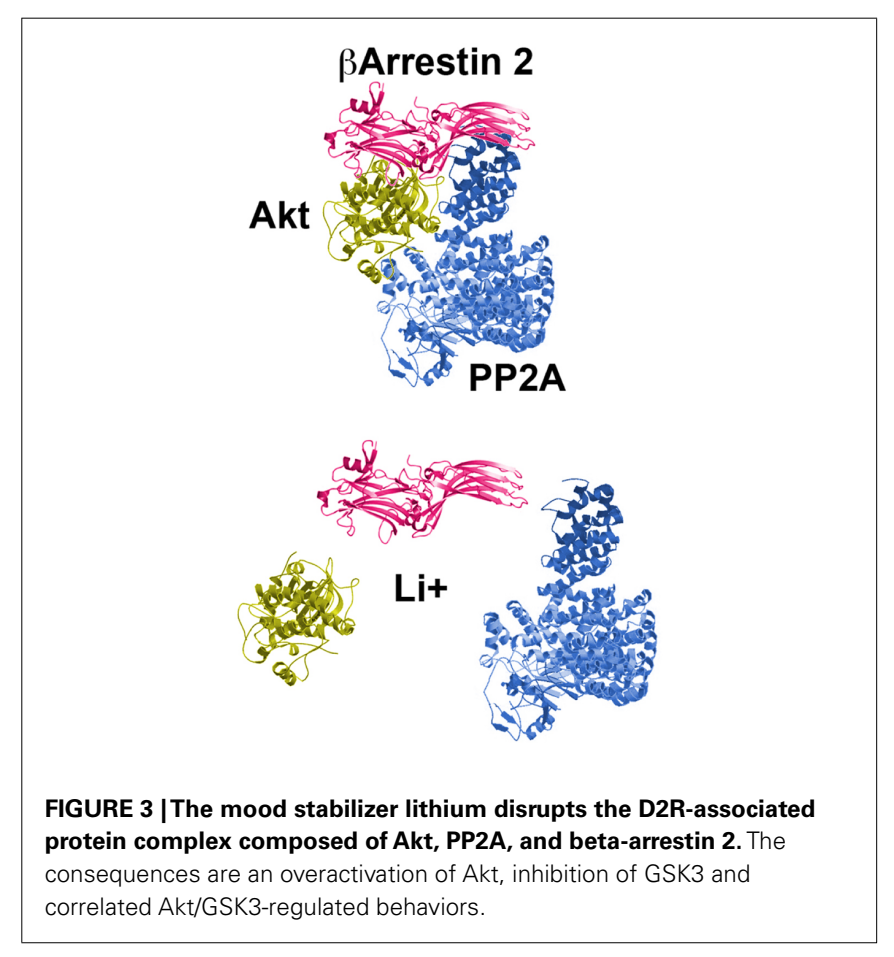

also acting on other "non-dopamine" receptor types (Meltzer, 1991; Kapur and Remington, 2001). Considering the role of D2R in regulating the $\beta$ Arr $2 / A k t / G S K 3$ pathway, it is not surprising that antipsychotics with D2R antagonist properties have been reported to activate Akt and inhibit GSK3 in vivo (Emamian et al., 2004; Alimohamad et al., 2005; Beaulieu et al., 2007a; Li et al., 2007). Among these, haloperidol prevents the inhibition of Akt and concomitant activation of GSK3 by dopamine (Beaulieu et al., 2004; Emamian et al., 2004). Similarly AA such as clozapine, olanzapine, risperidone, quetiapine, and ziprasidone, have been shown to activate Akt or mimic its activity by increasing GSK3 $\alpha$ and GSK3 $\beta$ phosphorylation in the striatum, cortex, and hippocampus (Alimohamad et al., 2005; Li et al., 2007; Beaulieu et al., 2009). Unfortunately, the functional involvement of $\beta$ Arr 2 has not been explored in these in vivo studies. However, in vitro experiments using bioluminescent resonance energy transfer (BRET) have suggested that both typical and AA may induce some of their effects by antagonizing the recruitment of $\beta A r r 2$ to the D2R long isoform (D2 ${ }_{\mathrm{L}} \mathrm{R}$; Masri et al., 2008). More specifically, this study has shown three different effects of antipsychotics on the inhibition of cAMP-synthesis and arrestin recruitment in response to $\mathrm{D} 2{ }_{\mathrm{L}} \mathrm{R}$ stimulation. Some drugs, like haloperidol, antagonized both the regulation of cAMP and the recruitment of $\beta A r r 2$ to the $D 2_{L} R$ with a similar efficacy. In contrast, other drugs like clozapine appeared to be stronger antagonists of $\beta A$ Arr 2 recruitment than of cAMP modulation. Finally, other antipsychotics like aripiprazole acted as partial antagonists of cAMP regulation while fully inhibiting $\beta$ Arr 2 recruitment. Taken together, these results suggest that antipsychotics share common antagonistic properties toward D2R/ $\beta$ Arr2-mediated signaling while having different effects on the control of cAMP production by this same receptor, at least in transfected cells. It would thus be interesting to explore the physiological action of each of these drugs on Akt and GSK3 in vivo 
to establish whether the effects of these psychoactive drugs are closely related to D2R/ $\beta$ Arr2/Akt/GSK3 signaling.

It should be noted however, the implication of $\mathrm{D} 2 \mathrm{R}$ in the regulation of Akt and GSK3 by AA can also be explained by other mechanisms. One alternative could involve serotonin neurotransmission. Indeed, most AAs are 5-HT2A receptors antagonists (Kapur and Remington, 2001). Interestingly, the 5-HT2A agonist 2,5-dimethoxy-4-iodoamphetamine (DOI) activates GSK3 in vivo (Li et al., 2004) while AA have the opposite effect on the activity of this kinase (Li et al., 2007). Furthermore, enhancers of serotonin neurotransmissions like serotonin reuptake inhibitors and fenfluramine or genetic manipulations decreasing serotonin synthesis have also been shown to affect GSK3 activity in vivo (Li et al., 2007; Beaulieu et al., 2008b; Figure 4). Additional characterization is therefore needed to determine the relative contribution of dopamine and serotonin receptors in the modulation of Akt/GSK3 by AA drugs and to define the roles that they may have in psychotic disorders.

\section{MOLECULAR TARGETS OF DOPAMINE REGULATED BY $\beta$ Arr2, Akt, AND GSK3 SIGNALING}

While several lines of evidence indicate a role for $\beta$ Arr2, Akt, and GSK3 in dopamine receptor signaling, there is little information on the nature of the molecular targets of these kinases that are affected by dopamine receptors in the basal ganglia or other brain regions. Akt and GSK3 have various substrates involved in numerous cellular processes linked to mental illnesses-associated physiological functions like cytoskeleton organization, trafficking, cell survival, apoptosis, and DNA transcription (Frame and Cohen, 2001; Woodgett, 2001). Here, we present three different molecular systems that are regulated by GSK3 and for which there are some evidences for direct involvement of dopamine receptor signaling: the direct GSK3 substrate $\beta$-catenin, ionotropic glutamate receptors, and the regulation of circadian rhythms.

\section{$\beta$-CATENIN}

$\beta$-catenin has multiple roles in the cell. This protein functions as a transcription factor and a scaffolding protein, which anchors the actin cytoskeleton as mediator of adherent junctions. $\beta$-catenin is a common component of the Wnt and Akt/GSK3 signaling pathway (For review: Freyberg et al., 2010). In the absence of Wnt stimulation, $\beta$-catenin forms a complex with GSK3 and several other proteins. This induces the phosphorylation of $\beta$-catenin by GSK3 and then its ubiquitination and proteasomal degradation (Doble and Woodgett, 2003). Conversely, activation of the Wnt receptor Frizzled leads to the disruption of this complex by the protein Disheveld (Dvl). Free $\beta$-catenin can then translocate to the nucleus and affect gene expression (Fukumoto et al., 2001). Interestingly, the regulation of the Akt/GSK3 signaling cascade by D2R and $\beta$ Arr 2 may affect $\beta$-catenin activity. Interestingly, chronic treatment with the mood stabilizer lithium in mice increases $\beta$-catenin levels in different brain regions such as the amygdala, striatum, hypothalamus, and hippocampus (O'Brien et al., 2004; Beaulieu et al., 2008a). It is has been shown that increased levels of striatal $\beta$-catenin in response to lithium is dependent upon the expression of $\beta$ Arr2 therefore suggesting that changes in $\beta$-catenin in response to lithium may arise from a disruption of $\beta$ Arr2-mediated D2R signaling (Beaulieu et al., 2008a). In addition, overexpression of $\beta$-catenin in mice reproduces the behavioral effects of the GSK3 inhibition

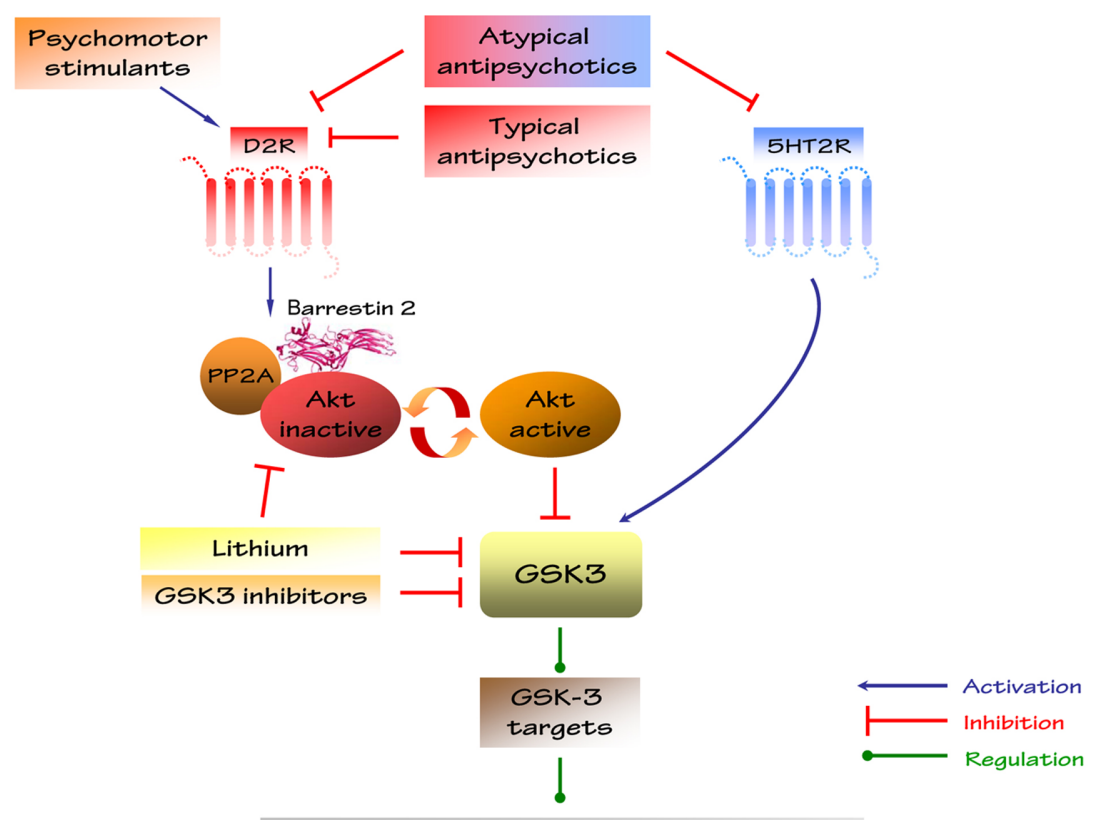

Monoamines-dependant behaviors

FIGURE 4 | Regulation of Akt/GSK3 signaling by drugs affecting dopamine and 5-HT neurotransmitter systems. Monoamines-dependent behaviors have been discovered in Akt1- and $\beta$ Arr2-KO mice and in GSK3 $\beta$ heterozygous mice. 
by lithium on dopamine-dependent locomotor hyperactivity and in tests evaluating antidepressant and anxiolytic effects of drugs in rodents (Gould et al., 2008). The functional consequences of these drugs could be mediated by the striatum, since the $\beta$ catenin forebrain-specific conditional knock-out mouse shows little behavioral changes (Gould et al., 2008). However, this still has to be established.

\section{GLUTAMATE RECEPTORS}

The modulation of GSK3 signaling by dopamine receptors also appears to regulate some functions of NMDA ionotropic glutamate receptors and associated synaptic plasticity (Chen et al., 2007). In particular, GSK3 activity modulates the development of long-term depression (LTD) in rat hippocampal slices, two processes regulated by ionotropic glutamate receptors (Zhu et al., 2007; Peineau et al., 2008). Furthermore, Akt/GSK3-mediated signaling appears to be responsible for the regulation of NMDA receptors by $\mathrm{D} 2 \mathrm{R}$ in response to high levels of dopamine in the rat frontal cortex (Li et al., 2009). Briefly, application of high concentrations of dopamine induces a reduction of NMDA current associated with the internalization of the NMDA receptor subunit NR2B both in cortical slice preparations and in vivo. The effect of elevated dopamine on NMDA receptor functions is dependent of D2R, GSK3, and PP2A and is not affected by inhibition of G proteins, therefore suggesting an involvement of $\beta$ Arr2-mediated signaling (Li et al., 2009). However, the contribution of $\beta$ Arr 2 to the regulation of NMDA receptor functions as a result of elevated dopamine levels has not been confirmed. Also, it remains unclear whether this type of regulation occurs in the striatum or if it is restricted to cortical neurons.

\section{REGULATION OF CLOCK GENE SIGNALING}

The deregulation of circadian rhythm is thought to be an integral part of human mental diseases like bipolar disorders and in particular seasonal affective disorders (Benedetti et al., 2004; Mansour et al., 2005). One of the first studies associating GSK3 to the regulation of circadian rhythm has been made in drosophila. Yuan et al. (2005) have shown that the fly GSK3 ortholog, Shaggy, is regulated by serotonin and affects the circadian cycle. Then, numerous studies have demonstrated the regulation of clock genes by GSK3 in mammals (Iitaka et al., 2005; Lamont et al., 2007). For example, the GSK3 inhibitor lithium affects the transcription of the clock gene Bmal1 (Lamont et al., 2007). In line with this, GSK3 $\beta$ can also regulate mammalian circadian protein functions in vitro (Iitaka et al., 2005). Interestingly, circadian rhythm-regulated gene expression and associated-behaviors can also be modulated by the D2R, which is known to regulate GSK3 (Doi et al., 2006; Yujnovsky et al., 2006). D2R is highly expressed in the retina and plays an important role in neural adaptation to light (Doi et al., 2006). Accordingly, activation of D2R stimulates CLOCK:BMAL1 functions through MAP Kinases pathways and could possibly regulate circadian gene expression through $\beta$ Arr2/Akt/GSK3 signaling (Sahar et al., 2010). This suggests a putative relevant link between circadian rhythm and dopamine receptor functions.

\section{CONCLUSION AND PERSPECTIVES}

The relatively recent identification of $G$ protein-independent $\beta$ Arr-mediated signaling of GPCR has radically changed our perception of the roles played by these molecules in dopamine receptor functions. From simple desensitization molecules, $\beta$ Arr are now seen as polyvalent GPCR-associated scaffolding proteins having complex and multiple functions in regulating the final outcome of receptor stimulation (Wei et al., 2003; GestyPalmer et al., 2006). Extensive and elegant research efforts have shown how downstream targets of dopamine receptors such as DARPP-32 can act as integrators and coincidence detectors modulating the outcome of dopamine receptor signaling in function of the activation of other neurotransmitter systems (Svenningsson et al., 2004). When put in this context, the dual functions of $\beta$ Arr add an extra layer of complexity to dopamine receptor signaling. Indeed the co-occurrence of $G$ protein-dependent and $\beta$ Arr-mediated responses reveals that dopamine receptors also exhibit signaling diversity. Through such diversity, a given receptor may regulate several modalities of signaling under different conditions or during different periods of its activation cycle. This can have several important physiological consequences and raises many pending questions that will have to be addressed further in future research.

First, signal diversity downstream of dopamine receptors may have a considerable impact on the development of pharmacological approaches to manipulate dopamine receptor functions. The assumption that a receptor is engaged in exclusively one type of signaling event regardless of its cellular composition has been the basis of the definition of the intrinsic drug efficacy (Galandrin et al., 2007). However, a context where dopamine receptor can elicit different cell signaling responses involving $G$ protein, $\beta$ Arr, or other signaling molecules has led to the suggestion that it may be possible to generate new biased ligands for dopamine receptors that would modulate one or another cell signaling mechanism preferentially (Beaulieu et al., 2007a). It is believed that such biased agonism can have important implications for drug development because intracellular signaling events mediated by these parallel pathways may have distinct physiological consequences. As discussed above, D2R has been shown to be one of the best examples of this duality in receptor signaling, because it is involved in the regulation of the $G$ protein-mediated functions and the $\beta$ Arr2-mediated Akt/GSK3 signaling cascade (Beaulieu et al., 2009). Although there are no known D2R ligands affecting specifically one or the other of these signaling modalities, it may be possible to develop drugs to selectively target one of these pathways. In fact, the ability of the mood stabilizer drug lithium to disrupt $\beta$ Arr2mediated Akt/GSK3 signaling and to suppress the behavioral effects that are related to enhanced dopaminergic transmission provides the first evidence for the activity of clinically effective compounds on $\beta$ Arr2 scaffolded signaling complexes downstream of the D2R (Beaulieu et al., 2008a, 2009; Rajagopal et al., 2010).

Prior to develop drugs acting preferentially on one or another cell signaling response, it would be important to decipher what is the relative role of these different modalities of signaling in regulating the final physiological outcome of dopamine receptor activation. This can be particularly important in the context of MAP kinase regulation. Indeed, ERK can be regulated by both $G$ protein/DARPP-32 and $\beta$ Arr2-mediated signaling events 
downstream of D1R (Valjent et al., 2006b; Urs et al., 2011). Considering the important role of this kinase in regulating both acute and long-term consequences of dopamine receptor signaling (Beaulieu et al., 2006; Valjent et al., 2006b), it would be important to establish what is the level of segregation (if any) between the functions exerted by ERK when it is activated by either mechanisms. This can be important since association with a $\beta$ Arr signaling complex may affect the subcellular localization of activated ERK and therefore change the nature of its substrates (Pierce and Lefkowitz, 2001). The same observations can also be made for the regulation of Akt and GSK3 by D2R since alternative mechanisms such as the transactivation of the BDNF receptor TrkB by dopamine receptors (Swift et al., 2011) may also affect Akt and GSK3 activity in specific neuronal populations.

Another pending issue is the nature of the contribution of $\beta$ Arr 1 in mediating dopamine receptor signaling. As of today, most of the attention has been focused on the role played by $\beta A$ Arr 2 in both D1R- and D2R-mediated signaling. However, behavioral evidence indicates that $\beta$ Arr 1-KO mice also exhibit behavioral responses to dopamine drugs that are compatible with a major role of $\beta$ Arr 1 in mediating some signaling responses in addition to its probable function in canonical homologous receptor desensitization (Gainetdinov et al., 2004).

\section{REFERENCES}

Ahn, S., Shenoy, S. K., Wei, H., and Lefkowitz, R. J. (2004). Differential kinetic and spatial patterns of betaarrestin and $G$ protein-mediated ERK activation by the angiotensin II receptor. J. Biol. Chem. 279, 35518-35525.

Alessi, D. R., Andjelkovic, M., Caudwell, B., Cron, P., Morrice, N., Cohen, P., and Hemmings, B. A. (1996). Mechanism of activation of protein kinase $\mathrm{B}$ by insulin and IGF-1. EMBO J. 15, 6541-6551.

Alimohamad, H., Rajakumar, N., Seah, Y. H., and Rushlow, W. (2005). Antipsychotics alter the protein expression levels of beta-catenin and GSK-3 in the rat medial prefrontal cortex and striatum. Biol. Psychiatry 57, 533-542.

Altar, C. A., Hunt, R. A., Jurata, L. W., Webster, M. J., Derby, E., Gallagher, P., Lemire, A., Brockman, J., and Laeng, P. (2008). Insulin, IGF-1, and muscarinic agonists modulate schizophreniaassociated genes in human neuroblastoma cells. Biol. Psychiatry 64, 1077-1087.

Bannon, M. J., Wolf, M. E., and Roth, R. H. (1983). Pharmacology of dopamine neurons innervating the prefrontal, cingulate and piriform cortices. Eur. J. Pharmacol. 92, 119-125.

Beaulieu, J. M., and Caron, M. G. (2008). Looking at lithium: molecular moods and complex behaviour. Mol. Interv. 8, 230-241.
Beaulieu, J. M., and Gainetdinov, R. R. (2011). The physiology, signaling, and pharmacology of dopamine receptors. Pharmacol. Rev. 63, 182-217.

Beaulieu, J. M., Gainetdinov, R. R., and Caron, M. G. (2007a). The Akt-GSK-3 signaling cascade in the actions of dopamine. Trends Pharmacol. Sci. 28, 166-172.

Beaulieu, J. M., Tirotta, E., Sotnikova, T. D., Masri, B., Salahpour, A., Gainetdinov, R. R., Borrelli, E., and Caron, M. G. (2007b). Regulation of Akt signaling by D2 and D3 dopamine receptors in vivo. J. Neurosci. 27, 881-885.

Beaulieu, J. M., Gainetdinov, R. R., and Caron, M. G. (2009). Akt/GSK3 signaling in the action of psychotropic drugs. Annu. Rev. Pharmacol. Toxicol. 49, 327-347.

Beaulieu, J. M., Marion, S., Rodriguiz, R. M., Medvedev, I. O., Sotnikova, T. D., Ghisi, V., Wetsel, W. C., Lefkowitz, R. J., Gainetdinov, R. R., and Caron, M. G. (2008a). A beta-arrestin 2 signaling complex mediates lithium action on behavior. Cell 132, 125-136.

Beaulieu, J. M., Zhang, X., Rodriguiz, R. M., Sotnikova, T. D., Cools, M. J., Wetsel, W. C., Gainetdinov, R. R., and Caron, M. G. (2008b). Role of GSK3 beta in behavioral abnormalities induced by serotonin deficiency. Proc. Natl. Acad. Sci. U.S.A. 105, 1333-1338.

Beaulieu, J. M., Sotnikova, T. D., Gainetdinov, R. R., and Caron, M. G. (2006). Paradoxical striatal cellular

In conclusion, the identification of cell signaling functions associated to $\beta$ Arr downstream of dopamine receptors underscores the intricate complexity of the intertwined mechanisms regulating and mediating neuronal communication in the basal ganglia. This is an essential step to understand the several roles played by these structures in the regulation of mood, cognition, affect, and movement. Furthermore, understanding these mechanisms may lead to the development of new drugs having the desired therapeutic effect and avoiding aversive and undesired side effects.

\section{ACKNOWLEDGMENTS}

This review was supported by an Operating Grant (NSA 93798) from Canadian Institutes of Health Research (CIHR) to JeanMartin Beaulieu. Jean-Martin Beaulieu is also supported by a Career development award from the Human Frontier Science Program, a National Alliance for Research on Schizophrenia and Depression (NARSAD), Young Investigator Award and hold a Canada research Chair in Molecular Psychiatry. Thomas Del'Guidice is a recipient of fellowships from the Fondation Robert Giffard and The Centre de Recherche sur le Cerveau, le Comportement et la Neuropsychiatrie (CRCN). Morgane Lemasson is a recipient of the Fonds de la Recherche et de la Santé du Québec (FRSQ).

signaling responses to psychostimulants in hyperactive mice. J. Biol. Chem. 281, 32072-32080.

Beaulieu, J. M., Sotnikova, T. D., Marion, S., Lefkowitz, R. J., Gainetdinov, R. R., and Caron, M. G. (2005). An Akt/beta-arrestin 2/PP2A signaling complex mediates dopaminergic neurotransmission and behavior. Cell 122, 261-273.

Beaulieu, J. M., Sotnikova, T. D., Yao, W. D., Kockeritz, L., Woodgett, J. R., Gainetdinov, R. R., and Caron, M. G. (2004). Lithium antagonizes dopamine-dependent behaviors mediated by an AKT/glycogen synthase kinase 3 signaling cascade. Proc. Natl. Acad. Sci. U.S.A. 101, 5099-5104.

Benedetti, F., Bernasconi, A., Lorenzi, C., Pontiggia, A., Serretti, A., Colombo, C., and Smeraldi, E. (2004). A single nucleotide polymorphism in glycogen synthase kinase 3-beta promoter gene influences onset of illness in patients affected by bipolar disorder. Neurosci. Lett. 355, 37-40.

Berhow, M. T., Hiroi, N., and Nestler, E. J. (1996). Regulation of ERK (extracellular signal regulated kinase), part of the neurotrophin signal transduction cascade, in the rat mesolimbic dopamine system by chronic exposure to morphine or cocaine. J. Neurosci. 16, 4707-4715

Bjorklund, A., and Stenevi, U. (1984). Intracerebral neural implants: neuronal replacement and reconstruction of damaged circuitries. Annu. Rev. Neurosci. 7, 279-308.
Blanco, C., Laje, G., Olfson, M., Marcus, S. C., and Pincus, H. A. (2002). Trends in the treatment of bipolar disorder by outpatient psychiatrists. Am. J. Psychiatry 159, 1005-1010.

Bohn, L. M., Gainetdinov, R. R., Sotnikova, T. D., Medvedev, I. O., Lefkowitz, R. J., Dykstra, L. A., and Caron, M. G. (2003). Enhanced rewarding properties of morphine, but not cocaine, in beta(arrestin)2 knock-out mice. J. Neurosci. 23, 10265-10273.

Bychkov, E., Ahmed, M. R., Dalby, K. N., and Gurevich, E. V. (2007). Dopamine depletion and subsequent treatment with L-DOPA, but not the long-lived dopamine agonist pergolide, enhances activity of the Akt pathway in the rat striatum. J. Neurochem. 102, 699-711.

Cade, J. F. (1949). Lithium salts in the treatment of psychotic excitement. Med. J. Aust. 2, 349-352.

Carlsson, A. (2001). A paradigm shift in brain research. Science 294, 1021-1024.

Chalecka-Franaszek, E., and Chuang, D. M. (1999). Lithium activates the serine/threonine kinase Akt-1 and suppresses glutamate-induced inhibition of Akt-1 activity in neurons. Proc. Natl. Acad. Sci. U.S.A. 96, 8745-8750.

Chen, G., Huang, L. D., Jiang, Y. M., and Manji, H. K. (1999). The mood-stabilizing agent valproate inhibits the activity of glycogen synthase kinase-3. J. Neurochem. 72, 1327-1330. 
Chen, P., Gu, Z., Liu, W., and Yan, Z. (2007). Glycogen synthase kinase 3 regulates $N$-methyl-D-aspartate receptor channel trafficking and function in cortical neurons. Mol. Pharmacol. 72, 40-51.

Claing, A., and Laporte, S. A. (2005). Novel roles for arrestins in G protein-coupled receptor biology and drug discovery. Curr. Opin. Drug Discov. Devel. 8, 585-589.

Claing, A., Laporte, S. A., Caron, M. G., and Lefkowitz, R. J. (2002). Endocytosis of $\mathrm{G}$ protein-coupled receptors: roles of $\mathrm{G}$ proteincoupled receptor kinases and betaarrestin proteins. Prog. Neurobiol.66, 61-79.

Cross, D. A., Alessi, D. R., Cohen, P., Andjelkovich, M., and Hemmings, B. A. (1995). Inhibition of glycogen synthase kinase- 3 by insulin mediated by protein kinase B. Nature 378 , 785-789.

Doble, B. W., and Woodgett, J. R. (2003). GSK-3: tricks of the trade for a multi-tasking kinase. J. Cell. Sci. 116(Pt 7), 1175-1186.

Doi, M., Yujnovsky, I., Hirayama, J., Malerba, M., Tirotta, E., SassoneCorsi, P., and Borrelli, E. (2006). Impaired light masking in dopamine D2 receptor-null mice. Nat. Neurosci. 9, 732-734.

Emamian, E. S., Hall, D., Birnbaum, M. J., Karayiorgou, M., and Gogos, J. A. (2004). Convergent evidence for impaired AKT1-GSK3beta signaling in schizophrenia. Nat. Genet. $36,131-137$.

Ferguson, S. S. (2001). Evolving concepts in G protein-coupled receptor endocytosis: the role in receptor desensitization and signaling. Pharmacol. Rev. 53, 1-24.

Ferguson, S. S., Downey, W. E. III, Colapietro, A. M., Barak, L. S., Ménard, L., and Caron, M. G. (1996). Role of beta-arrestin in mediating agonist-promoted G protein-coupled receptor internalization. Science 271, 363-366.

Frame, S., and Cohen, P. (2001). GSK3 takes centre stage more than 20 years after its discovery. Biochem. J. 359(Pt 1), 1-16.

Freyberg, Z., Ferrando, S. J., and Javitch, J. A. (2010). Roles of the Akt/GSK-3 and Wnt signaling pathways in schizophrenia and antipsychotic drug action. Am. J. Psychiatry 167, 388-396.

Fukumoto, S., Hsieh, C. M., Maemura, K., Layne, M. D., Yet, S. F., Lee, K. H., Matsui, T., Rosenzweig, A., Taylor, W. G., Rubin, J. S., Perrella, M. A., and Lee, M. E. (2001). Akt participation in the Wnt signaling pathway through Dishevelled. J. Biol. Chem. 276, 17479-17483.
Gainetdinov, R. R., Bohn, L. M., Sotnikova, T. D., Cyr, M., Laakso, A., Macrae, A. D., Torres, G. E., Kim, K. M., Lefkowitz, R. J., Caron, M. G., and Premont, R. T. (2003). Dopaminergic supersensitivity in $\mathrm{G}$ protein-coupled receptor kinase 6deficient mice. Neuron 38, 291-303.

Gainetdinov, R. R., Premont, R. T., Bohn, L. M., Lefkowitz, R. J., and Caron, M. G. (2004). Desensitization of $\mathrm{G}$ protein-coupled receptors and neuronal functions. Annu. Rev. Neurosci. 27, 107-144.

Gainetdinov, R. R., Wetsel, W. C., Jones, S. R., Levin, E. D., Jaber, M., and Caron, M. G. (1999). Role of serotonin in the paradoxical calming effect of psychostimulants on hyperactivity. Science 283, 397-401.

Galandrin, S., Oligny-Longpré, G., and Bouvier, M. (2007). The evasive nature of drug efficacy: implications for drug discovery. Trends Pharmacol. Sci. 28, 423-430.

Gerfen, C. R., and Surmeier, D. J. (2011). Modulation of striatal projection systems by dopamine. Annu. Rev. Neurosci. 34, 441-466.

Gesty-Palmer, D., Chen, M., Reiter, E., Ahn, S., Nelson, C. D., Wang, S., Eckhardt, A. E., Cowan, C. L., Spurney, R. F., Luttrell, L. M., and Lefkowitz, R. J. (2006). Distinct beta-arrestinand $G$ protein-dependent pathways for parathyroid hormone receptorstimulated ERK1/2 activation. J. Biol. Chem. 281, 10856-10864.

Girault, J. A., Valjent, E., Caboche, J., and Hervé, D. (2007). ERK2: a logical AND gate critical for drug-induced plasticity? Curr. Opin. Pharmacol. 7, 77-85.

Giros, B., Jaber, M., Jones, S. R., Wightman, R. M., and Caron, M. G. (1996). Hyperlocomotion and indifference to cocaine and amphetamine in mice lacking the dopamine transporter. Nature 379, 606-612.

Gould, T. D., K. C. O'Donnell, Picchini, A. M., Dow, E. R., Chen, G., and Manji, H. K. (2008). Generation and behavioral characterization of beta-catenin forebrainspecific conditional knock-out mice. Behav. Brain Res. 189, 117-125.

Gould, T. D., and Manji, H. K. (2005). Glycogen synthase kinase-3: a putative molecular target for lithium mimetic drugs. Neuropsychopharmacology 30, 1223-1237.

Iitaka, C., Miyazaki, K., Akaike, T., and Ishida, N. (2005). A role for glycogen synthase kinase-3beta in the mammalian circadian clock. J. Biol. Chem. 280, 29397-29402.

Jacinto, E., Facchinetti, V., Liu, D., Soto, N., Wei, S., Jung, S. Y., Huang, Q., Qin, J., and Su, B. (2006). SIN1/MIP1 maintains rictor-mTOR complex integrity and regulates Akt phosphorylation and substrate specificity. Cell 127, 125-137.

Jones, S. R., Gainetdinov, R. R., Wightman, R. M., and Caron, M. G. (1998). Mechanisms of amphetamine action revealed in mice lacking the dopamine transporter. J. Neurosci. 18, 1979-1986.

Kapur, S., and Remington, G. (2001). Atypical antipsychotics: new directions and new challenges in the treatment of schizophrenia. Annu. Rev. Med. 52, 503-517.

Kebabian, J. W., and Calne, D. B. (1979). Multiple receptors for dopamine. Nature 277, 93-96.

Kim, K. M., Valenzano, K. J., Robinson, S. R., Yao, W. D., Barak, L. S., and Caron, M. G. (2001). Differential regulation of the dopamine $\mathrm{D} 2$ and D3 receptors by $G$ protein-coupled receptor kinases and beta-arrestins. J. Biol. Chem. 276, 37409-37414.

Kravitz, A. V., Freeze, B. S., Parker, P. R., Kay, K., Thwin, M. T., Deisseroth, K., and Kreitzer, A. C. (2010). Regulation of parkinsonian motor behaviours by optogenetic control of basal ganglia circuitry. Nature 466, 622-626.

Krupnick, J. G., Goodman, O. B. Jr., Keen, J. H., and Benovic, J. L. (1997). Arrestin/clathrin interaction. Localization of the clathrin binding domain of nonvisual arrestins to the carboxy terminus. J. Biol. Chem. 272, 15011-15016.

Kuschinsky, K., and Hornykiewicz, O. (1974). Effects of morphine on striatal dopamine metabolism: possible mechanism of its opposite effect on locomotor activity in rats and mice. Eur. J. Pharmacol. 26, 41-50.

Lamont, E. W., Legault-Coutu, D., Cermakian, N., and Boivin, D. B. (2007). The role of circadian clock genes in mental disorders. Dialogues Clin. Neurosci. 9, 333-342.

Lan, H., Teeter, M. M., Gurevich, V. V., and Neve, K. A. (2009). An intracellular loop 2 amino acid residue determines differential binding of arrestin to the dopamine D2 and D3 receptors. Mol. Pharmacol. 75, 19-26.

Laporte, S. A., Miller, W. E., Kim, K. M., and Caron, M. G. (2002). beta-Arrestin/AP-2 interaction in $\mathrm{G}$ protein-coupled receptor internalization: identification of a beta-arrestin binging site in beta 2-adaptin. J. Biol. Chem. 277, 9247-9254.

Li, X., Bijur, G. N., and Jope, R. S. (2002). Glycogen synthase kinase3beta, mood stabilizers, and neuroprotection. Bipolar Disord. 4, 137-144.
Li, X., Rosborough, K. M., Friedman, A. B., Zhu, W., and Roth, K. A. (2007). Regulation of mouse brain glycogen synthase kinase-3 by atypical antipsychotics. Int. J. Neuropsychopharmacol. 10, 7-19.

Li, X., Zhu, W., Roh, M. S., Friedman, A. B., Rosborough, K., and Jope, R. S. (2004). In vivo regulation of glycogen synthase kinase-3beta (GSK3beta) by serotonergic activity in mouse brain. Neuropsychopharmacology 29, 1426-1431.

Li, Y. C., Xi, D., Roman, J., Huang, Y. Q., and Gao, W. J. (2009). Activation of glycogen synthase kinase-3 beta is required for hyperdopamine and D2 receptor-mediated inhibition of synaptic NMDA receptor function in the rat prefrontal cortex. J. Neurosci. 29, 15551-15563.

Lohse, M. J., Benovic, J. L., Caron, M. G., and Lefkowitz, R. J. (1990a). Multiple pathways of rapid beta 2-adrenergic receptor desensitization. Delineation with specific inhibitors. J. Biol. Chem. 265, 3202-3211.

Lohse, M. J., Benovic, J. L., Codina, J., Caron, M. G., and Lefkowitz, R. J. (1990b). beta-Arrestin: a protein that regulates beta-adrenergic receptor function. Science 248, 1547-1550.

Luttrell, L. M., and Gesty-Palmer, D. (2010). Beyond desensitization: physiological relevance of arrestindependent signaling. Pharmacol. Rev. 62, 305-330.

Luttrell, L. M., Roudabush, F. L., Choy, E. W., Miller, W. E., Field, M. E., Pierce, K. L., and Lefkowitz, R. J. (2001). Activation and targeting of extracellular signal-regulated kinases by beta-arrestin scaffolds. Proc. Natl. Acad. Sci. U.S.A. 98, 2449-2454.

Mansour, H. A., Wood, J., Chowdari, K. V., Dayal, M., Thase, M. E., Kupfer, D. J., Monk, T. H., Devlin, B., and Nimgaonkar, V. L. (2005). Circadian phase variation in bipolar I disorder. Chronobiol. Int. 22, 571-584.

Martelli, A. M., Evangelisti, C., Chiarini, F., and McCubrey, J. A. (2010). The phosphatidylinositol 3-kinase/Akt/mTOR signaling network as a therapeutic target in acute myelogenous leukemia patients. Oncotarget 1, 89-103.

Masri, B., Salahpour, A., Didriksen, M., Ghisi, V., Beaulieu, J. M., Gainetdinov, R. R., and Caron, M. G. (2008). Antagonism of dopamine D2 receptor/beta-arrestin 2 interaction is a common property of clinically effective antipsychotics. Proc. Natl. Acad. Sci. U.S.A. 105, 13656-13661. 
Meltzer, H.Y. (1991). The mechanism of action of novel antipsychotic drugs. Schizophr. Bull. 17, 263-287

Miller, C. A., and Marshall, J. F. (2005). Molecular substrates for retrieval and reconsolidation of cocaineassociated contextual memory. $\mathrm{Neu}$ ron $47,873-884$

Missale, C., Nash, S. R., Robinson, S. W., Jaber, M., and Caron, M. G. (1998). Dopamine receptors: from structure to function. Physiol. Rev. $78,189-225$.

Oakley, R. H., Laporte, S. A., Holt, J. A., Barak, L. S., and Caron, M. G. (2001). Molecular determinants underlying the formation of stable intracellular $G$ proteincoupled receptor-beta-arrestin complexes after receptor endocytosis*. J. Biol. Chem. 276, 19452-19460.

O’Brien, W. T., Harper, A. D., Jové, F., Woodgett, J. R., Maretto, S., Piccolo, S., and Klein, P. S. (2004). Glycogen synthase kinase-3beta haploinsufficiency mimics the behavioral and molecular effects of lithium. $J$. Neurosci. 24, 6791-6798.

O’Brien, W. T., and Klein, P. S. (2009). Validating GSK3 as an in vivo target of lithium action. Biochem. Soc. Trans. 37(Pt 5), 1133-1138.

Pan, J. Q., Lewis, M. C., Ketterman, J. K., Clore, E. L., Riley, M., Richards, K. R., Berry-Scott, E., Liu, X., Wagner, F. F., Holson, E. B., Neve, R. L., Biechele, T. L., Moon, R. T., Scolnick, E. M., Petryshen, T. L., and Haggarty, S. J. (2011). AKT kinase activity is required for lithium to modulate mood-related behaviors in mice. Neuropsychopharmacology 36, 1397-1411.

Parent, M. B., Habib, M. K., and Baker, G. B. (2000). Time-dependent changes in brain monoamine oxidase activity and in brain levels of monoamines and amino acids following acute administration of the antidepressant/antipanic drug phenelzine. Biochem. Pharmacol. 59, 1253-1263.

Peineau, S., Bradley, C., Taghibiglou, C., Doherty, A., Bortolotto, Z. A., Wang, Y. T., and Collingridge, G. L. (2008). The role of GSK-3 in synaptic plasticity. Br. J. Pharmacol. 153(Suppl. 1), S428-37.

Phiel, C. J., and Klein, P. S. (2001). Molecular targets of lithium action. Annu. Rev. Pharmacol. Toxicol.41,789-813.

Pierce, K. L., and Lefkowitz, R. J. (2001). Classical and new roles of betaarrestins in the regulation of Gprotein-coupled receptors. Nat. Rev. Neurosci. 2, 727-733.

Pitcher, J. A., Hall, R. A., Daaka, Y., Zhang, J., Ferguson, S. S., Hester, S.,
Miller, S., Caron, M. G., Lefkowitz, R. J., and Barak, L. S. (1998). The $\mathrm{G}$ protein-coupled receptor kinase 2 is a microtubule-associated protein kinase that phosphorylates tubulin. J. Biol. Chem. 273, 12316-12324.

Premont, R. T. (2005). Once and future signaling: $G$ protein-coupled receptor kinase control of neuronal sensitivity. Neuromolecular Med. 7 , 129-147.

Premont, R. T., and Gainetdinov, R. R. (2007). Physiological roles of $\mathrm{G}$ protein-coupled receptor kinases and arrestins. Annu. Rev. Physiol. 69, 511-534.

Rajagopal, S., Rajagopal, K., and Lefkowitz, R. J. (2010). Teaching old receptors new tricks: biasing seventransmembrane receptors. Nat. Rev. Drug Discov. 9, 373-386.

Ramsey, A. J., Laakso, A., Cyr, M., Sotnikova, T. D., Salahpour, A., Medvedev, I. O., Dykstra, L. A., Gainetdinov, R. R., and Caron, M. G. (2008). Genetic NMDA receptor deficiency disrupts acute and chronic effects of cocaine but not amphetamine. Neuropsychopharmacology 33, 2701-2714.

Rashid, A. J., So, C. H., Kong, M. M., Furtak, T., El-Ghundi, M., Cheng, R., O'Dowd, B. F., and George, S. R. (2007). D1-D2 dopamine receptor heterooligomers with unique pharmacology are coupled to rapid activation of Gq/11 in the striatum. Proc. Natl. Acad. Sci. U.S.A. 104, 654-659.

Rossig, L., Badorff, C., Holzmann, Y., Zeiher, A. M., and Dimmeler, S. (2002). Glycogen synthase kinase3 couples AKT-dependent signaling to the regulation of p21Cip1 degradation. J. Biol. Chem. 277, 9684-9689.

Sahar, S., Zocchi, L., Kinoshita, C., Borrelli, E., and Sassone-Corsi, P. (2010). Regulation of BMAL1 protein stability and circadian function by GSK3beta-mediated phosphorylation. PLoS ONE 5, e8561. doi: 10.1371/journal.pone.0008561

Santini, E., Valjent, E., Usiello, A., Carta, M., Borgkvist, A., Girault, J. A., Hervé, D., Greengard, P., and Fisone, G. (2007). Critical involvement of cAMP/DARPP-32 and extracellular signal-regulated protein kinase signaling in L-DOPA-induced dyskinesia. J. Neurosci. 27, 6995-7005

Scheid, M. P., and Woodgett, J. R. (2001). PKB/AKT: functional insights from genetic models. Nat. Rev. Mol. Cell Biol. 2, 760-768.

Schou, M., Juel-Nielsen, N., Stromgren, E., and Voldby, H. (1954). The treatment of manic psychoses by the administration of lithium salts.
J. Neurol. Neurosurg. Psychiatr. 17, 250-260.

Shenoy, S. K., and Lefkowitz, R. J. (2005). Angiotensin II-stimulated signaling through $G$ proteins and beta-arrestin. Sci. STKE 2005, cm 14 .

Shuen, J. A., Chen, M., Gloss, B., and Calakos, N. (2008). DrdlatdTomato BAC transgenic mice for simultaneous visualization of medium spiny neurons in the direct and indirect pathways of the basal ganglia. J. Neurosci. 28 , 2681-2685.

Snyder, S. H. (1976). The dopamine hypothesis of schizophrenia: focus on the dopamine receptor. Am. J. Psychiatry 133, 197-202.

Souza, B. R., Romano-Silva, M. A., and Tropepe, V. (2011). Dopamine D2 receptor activity modulates Akt signaling and alters GABAergic neuron development and motor behavior in zebrafish larvae. J. Neurosci. 31 , 5512-5525.

Spano, P. F., Govoni, S., and Trabucchi, M. (1978). Studies on the pharmacological properties of dopamine receptors in various areas of the central nervous system. Adv. Biochem. Psychopharmacol. 19, 155-165.

Stambolic, V., Ruel, L., and Woodgett, J. R. (1996). Lithium inhibits glycogen synthase kinase- 3 activity and mimics wingless signalling in intact cells. Curr. Biol. 6, 1664-1668.

Stambolic, V., and Woodgett, J. R. (1994). Mitogen inactivation of glycogen synthase kinase- 3 beta in intact cells via serine 9 phosphorylation. Biochem. J. 303(Pt 3), 701-704.

Svenningsson, P., Nishi, A., Fisone, G. Girault, J. A., Nairn, A. C., and Greengard, P. (2004). DARPP-32: an integrator of neurotransmission. Annu. Rev. Pharmacol. Toxicol. 44, 269-296.

Swift, J. L., Godin, A. G., Doré, K., Freland, L., Bouchard, N., Nimmo, C., Sergeev, M., De Koninck, Y., Wiseman, P. W., and Beaulieu, J. M. (2011). Quantification of receptor tyrosine kinase transactivation through direct dimerization and surface density measurements in single cells. Proc. Natl. Acad. Sci. U.S.A. 108, 7016-7021.

Urs, N. M., Daigle, T. L., and Caron, M. G. (2011). A dopamine D1 receptor-dependent beta-arrestin signaling complex potentially regulates morphine-induced psychomotor activation but not reward in mice. Neuropsychopharmacology 36, 551-558.

Valjent, E., Bertran-Gonzalez, J., Hervé, D., Fisone, G., and Girault, J. A.
(2009). Looking BAC at striatal signaling: cell-specific analysis in new transgenic mice. Trends Neurosci. 32, 538-547.

Valjent, E., Corvol, J. C., Pages, C., Besson, M. J., Maldonado, R., and Caboche, J. (2000). Involvement of the extracellular signal-regulated kinase cascade for cocaine rewarding properties. J. Neurosci. 20, 8701-8709.

Valjent, E., Corvol, J. C., Trzaskos, J. M., Girault, J. A., and Hervé, D. (2006a). Role of the ERK pathway in psychostimulant-induced locomotor sensitization. $\mathrm{BMC} \mathrm{Neu-}$ rosci. 7, 20. doi: 10.1186/1471-22027-20

Valjent, E., Corbille, A. G., BertranGonzalez, J., Hervé, D., and Girault, J. A. (2006b). Inhibition of ERK pathway or protein synthesis during reexposure to drugs of abuse erases previously learned place preference. Proc. Natl. Acad. Sci. U.S.A. 103, 2932-2937.

Valjent, E., Herve, D., and Girault, J. A. (2005). Drugs of abuse, protein phosphatases, and ERK pathway. Med. Sci. (Paris) 21, 453-454.

Wei, H., Ahn, S., Barnes, W. G., and Lefkowitz, R. J. (2004). Stable interaction between beta-arrestin 2 and angiotensin type 1A receptor is required for beta-arrestin 2mediated activation of extracellular signal-regulated kinases 1 and 2. J. Biol. Chem. 279, 48255-48261.

Wei, H., Ahn, S., Shenoy, S. K., Karnik, S. S., Hunyady, L., Luttrell, L. M., and Lefkowitz, R. J. (2003). Independent beta-arrestin 2 and $\mathrm{G}$ protein-mediated pathways for angiotensin II activation of extracellular signal-regulated kinases 1 and 2. Proc. Natl. Acad. Sci. U.S.A. 100 , 10782-10787.

Woodgett, J. R. (1990). Molecular cloning and expression of glycogen synthase kinase-3/factor A. EMBO J. 9, 2431-2438.

Woodgett, J. R. (2001). Judging a protein by more than its name: GSK-3. Sci. STKE 2001, re12.

Woodgett, J. R. (2003). Physiological roles of glycogen synthase kinase3: potential as a therapeutic target for diabetes and other disorders. Curr. Drug Targets Immune Endocr. Metabol. Disord. 3, 281-290.

Yamada, T., Katagiri, H., Asano, T., Tsuru, M., Inukai, K., Ono, H., Kodama, T., Kikuchi, M., and Oka, Y. (2002). Role of PDK1 in insulinsignaling pathway for glucose metabolism in 3T3-L1 adipocytes. Am. J. Physiol. Endocrinol. Metab. 282, E1385-E1394. 
Yuan, Q., Lin, F., Zheng, X., and Sehgal, A. (2005). Serotonin modulates circadian entrainment in Drosophila. Neuron 47, 115-127.

Yujnovsky, I., Hirayama, J., Doi, M., Borrelli, E., and Sassone-Corsi, P. (2006). Signaling mediated by the dopamine $\mathrm{D} 2$ receptor potentiates circadian regulation by ClOCK:BMAL1. Proc. Natl. Acad. Sci. U.S.A. 103, 6386-6391.
Zhu, L. Q., Wang, S. H., Liu, D., Yin, Y. Y., Tian, Q., Wang, X. C., Wang, Q., Chen, J. G., and Wang, J. Z. (2007). Activation of glycogen synthase kinase-3 inhibits longterm potentiation with synapseassociated impairments. J. Neurosci. 27, 12211-12220.

Conflict of Interest Statement: The authors declare that the research was conducted in the absence of any commercial or financial relationships that could be construed as a potential conflict of interest.

Received: 13 May 2011; paper pending published: 06 June 2011; accepted: 17 August 2011; published online: 06 September 2011.

Citation: Del'Guidice T, Lemasson $M$ and Beaulieu J-M (2011) Role

of beta-arrestin 2 downstream of dopamine receptors in the basal ganglia. Front. Neuroanat. 5:58. doi: 10.3389/fnana.2011.00058

Copyright (c) 2011 Del'Guidice, Lemasson and Beaulieu. This is an open-access article subject to a non-exclusive license between the authors and Frontiers Media $S A$, which permits use, distribution and reproduction in other forums, provided the original authors and source are credited and other Frontiers conditions are complied with. 